\title{
IMPLEMENTASI PERATURAN PEMERINTAH NO. 24 TAHUN 1997 TENTANG PENDAFTARAN TANAH DIKAITKAN DENGAN MODEL JUAL BELI TANAH MENURUT HUKUM ADAT DI TANJUNGSARI, KABUPATEN BOGOR
}

\author{
(Implementation of Government Regulations Number 24 Year 1997 concerning Land Registration \\ Related with Model of Land Sale and Purchase According to Customary Law in Tanjungsari, Bogor \\ District)
}

\author{
Wicipto Setiadi \\ Fakultas Hukum, Universitas Pembangunan Nasional "Veteran" Jakarta \\ Jl. RS Fatmawati, Cilandak, Jakarta \\ E-mail: wiciptos@gmail.com \\ Muhammad Arafah Sinjar \\ Fakultas Hukum, Universitas Pembangunan Nasional "Veteran" Jakarta \\ Jl. RS Fatmawati, Cilandak, Jakarta \\ E-mail:m.arafah.sinjar@gmail.com \\ Heru Sugiyono \\ Fakultas Hukum, Universitas Pembangunan Nasional "Veteran" Jakarta \\ Jl. RS Fatmawati, Cilandak, Jakarta \\ E-mail: heru.sugiyono@yahoo.com
}

Naskah diterima: 15 Februari 2019; revisi: 29 Maret 2019 2019; disetujui: 1 April 2019

\section{Abstrak}

Dalam Peraturan Pemerintah No. 24 Tahun 1997 tentang Pendaftaran Tanah mensyaratkan peralihan hak milik atas tanah harus dibuktikan dengan akta yang dibuat oleh Pejabat Pembuat Akta Tanah. Namun pada sebagian masyarakat Desa Tanjungsari, Kabupaten Bogor, jual beli atas tanah masih memakai tata cara hukum adat yakni tanpa melalui PPAT. Penelitian ini bertujuan untuk mengetahui faktor-faktor yang menyebabkan transaksi jual beli tanah di Desa Tanjungsari yang masih dilakukan dengan tata cara hukum adat, kemudian bagaimana implementasi peraturan pemerintah tersebut terkait model jual beli tanah menurut adat serta bagaimana proses pendaftarannya. Dalam penelitian yang menggunakan metode yuridis normatif ini ditemukan bahwa peraturan pemerintah tersebut dalam implementasinya masih belum dapat berjalan dengan baik antara lain karena tidak adanya unsur pemaksa dan sanksi yang tegas terhadap pelanggaran peraturan pemerintah tersebut, selain juga ada faktor budaya masyarakat yang turut andil mengakibatkan kurang berjalannya beberapa ketentuan dalam peraturan pemerintah. Oleh karena itu perlu dukungan sosialisasi dan penyuluhan hukum mengenai ketentuan dalam peraturan pemerintah tersebut dan juga dukungan berupa peningkatan kapasitas pejabat pertanahan untuk dapat memberikan pendampingan bagi masyarakat.

Kata kunci: jual beli tanah, hukum adat, tanjungsari

\begin{abstract}
In Government Regulation Number 24 year 1997 concerning Land Registration requires the transfer of land ownership rights to be proven by a deed made by the Land Deed Making Officer (PPAT). However, in the majority of the people of Tanjungsari Village, Bogor Regency, buying and selling land still uses customary law procedures, ie without PPAT. This study aims to determine the factors that cause land sale and purchase transactions in Tanjungsari Village which are still carried out by the procedure of customary law, then how the implementation of PP number 24 year 1997 concerning the model of land sale and purchase according to custom and how the registration process. The results of the study, using juridical normative method, indicates that the government regulation is still not implemented well because there's no clear punishment if the regulation is breached. The culture of the society also plays some role in this case. Therefore the support of legal education and socialization on the government regulation provisions is urgently needed. The capacity of the officer also need to be enhanced to they can assist the society well.
\end{abstract}

Keywords: sale and purchase, customary law, Tanjungsari 


\section{A. Pendahuluan}

Manusia adalah makhluk yang tidak dapat dipisahkan dari tanah, karena tanah merupakan pijakan dasar yang sangat penting dan sakral. Manusia lahir dan berkembang tidak lepas dari tanah, di atas tanah manusia membuat tempat tinggal, rumah, usaha, berkebun, bertani, bercocok tanam dan menata alam sesuai kodrat manusia yang memang disediakan oleh Penciptanya untuk dijaga dan dikelola dengan baik dan amanah.

Menurut J.B.A.F. Polak, hubungan manusia dengan tanah sepanjang sejarah terjadi dalam 3 (tiga) tahap berikut, yaitu:

1. Tahap pertama, yaitu tahap di mana manusia memperoleh kehidupannya dengan cara memburu binatang, mencari buah-buahan hasil hutan, mencari ikan di sungai atau danau. Mereka hidup tergantung dari persediaan hutan, mereka hidup mengembara dari tempat yang satu ke tempat yang lain.

2. Tahap kedua, yaitu bahwa pada tahap ini manusia sudah mulai mengenal cara bercocok tanam. Manusia mulai menetap di suatu tempat tertentu selama menunggu hasil tanaman. Ikatan terhadap tanahpun semakin erat oleh karena cara beternak yang dikenal manusia dan bersamaan dengan pengenalan cara bercocok tanam.

3. Tahap ketiga, yaitu tahap di mana manusia mulai menetap di suatu tempat tertentu dan tidak ada lagi perpindahan periodik. Manusia sudah mulai terikat pada penggunaan ternak untuk membantu usaha-usaha pertanian. Untuk kelangsungan hidupnya sudah mulai dari hasil pertanian dan peternakan. Juga, pada tahap ini manusia mulai terjamin hidupnya dengan mengandalkan hasilhasil pertanian dan peternakan daripada hidup mengembara. Mulai juga merasakan adanya surplus hasil-hasil produksi, corak pertanian, mengelola sendiri, menunggu hasil pertanian untuk jangka waktu yang lama, kemudian memungut hasilnya yang kemudian mendorong ke arah pemilikan tanah (individual), meskipun masih tunduk pada kehidupan persekutuan. Pada saat ini manusia mulai menetap dan mengenal pertukangan, terdapat surplus hasil pertanian dan kerajinan pada kelompok hidup orang-orang yang telah menetap. Keadaan ini mendorong lahirnya kelompok orang-orang yang mulai mengkhususkan dirinya sebagai penjaga keamanan dan melindungi masyarakat dari gangguan keamanan dari perampokan. ${ }^{1}$

Menurut penjelasan pasal 1 UndangUndang Nomor 5 Tahun 1960 tentang Peraturan Dasar Pokok-pokok Agraria (UUPA), tanah adalah permukaan bumi. Hal mana mengenai penggunaannya meliputi bagian tubuh bumi yang di bawahnya dan bagian ruang di atasnya sesuai dengan tujuan penggunaannya.

Tanah mempunyai arti yang sangat strategis karena merupakan salah satu sumber utama penghidupan dan kehidupan manusia. Di atas tanah tersebut manusia berpijak, bertempat tinggal, hidup, bercocok tanam, membangun jalan, sekolah, lapangan olahraga, industri dan segala fasilitas lainnya yang dibutuhkan dalam kehidupan bermasyarakat. Kebutuhan akan tanah dari hari ke hari semakin meningkat, hal ini lebih disebabkan karena meningkatnya 
jumlah penduduk dan kegiatan pembangunan, sedangkan luas tanah terbatas atau tetap. Meningkatnya pembangunan di segala bidang dan adanya tuntutan mutu kehidupan yang lebih baik sebagai dampak positif dari keberhasilan pembangunan yang sedang dilaksanakan mengakibatkan permintaan kebutuhan atas tanah menjadi semakin meningkat pula.

Dengan meningkatnya permintaan kebutuhan atas tanah, sebagai konsekuensi logisnya maka telah meningkat pula berbagai masalah pertanahan yang muncul ke permukaan dan menjadi pusat perhatian masyarakat luas. Hal ini dapat dilihat dari banyaknya keluhan masyarakat berupa pengaduan dan pernyataan tidak puas yang disampaikan baik melalui media massa atau melalui media elektronik lainnya maupun langsung kepada kantor pertanahan setempat.

Permasalahan utama pertanahan pada dasarnya berkaitan dengan hak atas tanah, baik yang dimiliki oleh perorangan maupun oleh badan hukum. Salah satu hak atas tanah berdasarkan Pasal 16 UUPA adalah Hak Milik atas Tanah. Pasal 20 ayat (1) UUPA menentukan bahwa: "Hak milik adalah hak turun-temurun, terkuat dan terpenuh yang dapat dipunyai orang atas tanah, dengan mengingat ketentuan Pasal 6. "Turun temurun artinya hak milik atas tanah tidak hanya berlangsung selama hidup orang yang menjadi pemegang hak atas tanah, tetapi dapat diwariskan dan dilanjutkan oleh ahli warisnya apabila pewaris meninggal dunia. Selain itu jangka waktu hak milik atas tanah tidak terbatas. Terkuat menunjukan bahwa hak milik merupakan induk dari macam-macam hak atas tanah lainnya sehingga dapat dibebani hak guna bangunan, hak pakai dan hak sewa.
Terpenuh menunjukkan wewenang pemegang hak milik dalam penggunaan tanahnya dapat untuk pertanian, jual-beli, hibah.

Menurut Rosnidar, kebutuhan tanah yang bersifat pokok adalah tanah mempunyai kedudukan yang tinggi bagi kehidupan manusia, sebagai tempat ia dilahirkan, dibesarkan, membangun kehidupannya sebagai tempat tinggal, sebagai sumber nafkah, dan juga kalau sudah meninggal kemudian. Hubungan yang bersifat ekonomi tersebut ditunjukkan dalam semboyan orang jawa yang mengatakan "sedhunuk bathuk senyarii bumi" (satu jengkal tanahpun akan diperjuangkan meski mengorbankan nyawa). ${ }^{2}$ Dengan menjadikan tanah sebagai kebutuhan pokok, maka setiap manusia selalu berusaha untuk dapat memiliki dan menguasainya melalui berbagai cara. Kepemilikan hak atas tanah dapat diperoleh melalui pewarisan, jual beli atau hibah.

Peralihan hak kepemilikan atas tanah diatur dalam ketentuan Undang-Undang Republik Indonesia No. 5 tahun 1960 tentang Peraturan Dasar Pokok-Pokok Agraria (UUPA) khususnya pasal 26 yaitu, setiap perbuatan yang dimaksud memindahkan hak milik atas tanah diatur dengan Peraturan Pemerintah. Sehubungan dengan hal tersebut, pasal 19 UUPA jo. Pasal 37 ayat (1) Peraturan Pemerintah Nomor 24 tahun 1997 tentang Pendaftaran Tanah (PP No. 24 Tahun 1997) menyebutkan, Peralihan hak atas tanah dan hak milih atas satuan rumah susun melalui jual beli, tukar menukar, hibah, permasalahan dalam perusahaan dan perbuatan hukum pemindahan hak lainnya, kecuali pemindahan hak melalui lelang hanya dapat didaftarkan jika dibuktikan dengan akta yang dibuat oleh Pejabat Pembuat Akte Tanah

\footnotetext{
Rosnidar Sembiring, Hukum Pertanahan Adat (Depok: Rajawali Pers, 2017), hlm. 3.
} 
(PPAT) yang berwenang menurut ketentuan peraturan perundang-undangan yang berlaku.

Kendatipun dalam Peraturan Pemerintah Nomor 24 tahun 1997 mensyaratkan peralihan hak milik atas tanah harus dibuktikan dengan akta yang dibuat oleh PPAT, namun adakalanya dalam melakukan transaksi terkait peralihan hak atas tanah melalui jual beli, sebagian masyarakat masih memakai tatacara hukum adat. Jual beli menurut hukum adat merupakan suatu perbuatan hukum di mana penjual menyerahkan tanah yang dijualnya kepada pembeli untuk selama-lamanya meskipun harga yang dibayarkan baru sebagian tanpa diikat akte perjanjian jual beli sebagaimana disyaratkan dalam ketentuan peraturan perundangundangan. Pada prinsipnya jual beli tanah dianggap sudah sah bilamana pihak pembeli tanah telah menyerahkan uang atau harga jual beli yang disepakati oleh kedua belah pihak di hadapan Kepala Desa, dan sudah dianggap aman dan terang. Mereka cukup hanya bermodalkan kuitansi tanda terima uang pembayaran di hadapan Kepala Desa atau Ketua Adat. Sistem jual beli tanah demikian, dianggap aman dan tidak terjadi pelanggaran, sehingga telah beralih dari penjual kepada pembeli setelah adanya penyerahan uang dengan disaksikan oleh Kepala Desa dan Tokoh Masyarakat Desa. Dalam praktik, tanda bukti hanya berupa kuitansi tanda pembayaran atau kertas segel saja. Menurut Dewi Wulansari bahwa: "Agar transaksi tanah itu sah, artinya dalam pembuatan hukum atau mendapat perlindungan hukum wajib dilakukan bantuan Kepala persekutuan agar perbuatan hukum ini menjadi terang dan atas bantuan Kepala persekutuan lazimnya menerima uang saksi". ${ }^{3}$
Jual beli tanah menurut hukum adat, tidak dibuktikan dengan akta jual beli tanah yang dibuat dihadapan Pejabat Pembuat Akta Tanah (PPAT) sebagaimana ditetapkan dalam PP Nomor 24 Tahun 1997. Bilamana dilihat dari ketentuan peraturan perundang-undangan, jual beli tanah menurut hukum adat tidak ada kepastian hukum terhadap status tanahnya bagi pemilik, karena peralihan haknya tidak dibuktikan dengan akta yang dibuat PPAT sebagai salah satu persyaratan pendaftaran untuk memperoleh sertifikat hak kepemilikan sebagai tanda bukti kuat.

Seperti halnya pada sebagian masyarakat Desa Tanjungsari - Kabupaten Bogor, masih melakukan transaksi jual beli tanah melalui sistem adat. Transaksi jual beli tanah oleh sebagian masyarakat di Desa Tanjungsari dilakukan cukup dihadapan Kepala Desa atau dengan disaksikan oleh tokoh masyarakat desa. Dalam praktik, tanda bukti peralihan hak atas tanah hanya berupa kuitansi tanda pembayaran atau kertas segel saja.

Berdasarkan latar belakang tersebut diatas, Tim Peneliti hendak menguraikan faktor-faktor yang menyebabkan transaksi jual beli tanah di Desa Tanjungsari masih dilakukan dengan sistem adat, kemudian bagaimana implementasi PP No. 24 Tahun 1997 dikaitkan dengan model jual beli menurut hukum adat di Desa Tanjungsari. Terakhir, bagaimana proses pendaftaran tanah untuk mendapatkan sertifikat sebagai bukti kepemilikan hak atas tanah yang dibeli dengan model jual beli menurut sistem hukum adat.

\section{B. Metode Penelitian}

Dalam melakukan penelitian, penulis menggunakan metode penelitian hukum yuridis

Dewi Wulansari, Hukum Adat Indonesia Suatu Pengantar (Jakarta:Rafika Aditama, 2010), hlm. 90. 
normatif. Metode penelitian hukum normatif pada dasarnya meneliti kaidah-kaidah hukum dan asas-asas hukum, menelaah permasalahan hukum yang dikemukakan dengan berpedoman pada data sekunder, yaitu bahan hukum primer, sekunder dan tersier. Bahan hukum primer yang dimaksud adalah UUD 1945, undang-undang yang relevan lainnya, peraturan pemerintah dan peraturan pelaksanaan lainnya yang relevan dengan judul artikel ini. Selanjutnya Tim Peneliti dalam penyusunan artikel ini juga menggunakan hukum sekunder yaitu doktrin, pendapat ahli, hasil karya ilmiah dalam berbagai jurnal ilmiah yang terkait dengan jual beli melaui sistem adat. Termasuk pula dalam bahan hukum sekunder adalah wawancara dengan narasumber sebagai pendukung bahan hukum primer. Data yang terkumpul diatas yang berasal dari data sekunder, baik dari berbagai peraturan perundang-undangan, buku-buku dari berbagai literature, juga penelusuran melalui jurnal-jurnal ilmiah, maupun lainnya kemudian dialkukan analisis dengan menggunakan metode analisis kualitatif.

\section{Pembahasan}

\section{Faktor-Faktor Yang Menyebabkan Transaksi Jual Beli Tanah Di Desa Tanjungsari Masih Dilakukan Dengan Sistem Adat}

Desa Tanjungsari adalah salah satu desa di wilayah Kecamatan Tanjungsari dengan data sebagai berikut: 1) luas wilayah kurang lebih $760,15 \mathrm{Ha}$; 2) secara administrasi terbagi dalam 4 Dusun, 8 Rukun Warga (RW) dan 18 Rukun Tetangga (RT); 3) batas-batas wilayah sebagai berikut: sebelah Utara berbatasan dengan Desa Pasirtanjung, sebelah Timur berbatasan dengan Desa Simarasa, sebelah Selatan berbatasan dengan Desa Simarasa, dan sebelah Barat berbatasan dengan Desa Sibadak. Jarak antara Kantor Desa Tanjungsari ke Ibu Kota Kecamatan Tanjungsari: 0,5 Km; ke Ibu Kota Kabupaten Bogor: $67 \mathrm{Km}$; ke Ibu Kota Provinsi Jawa Barat: 101 Km; ke Ibu Kota Negara RI (Jakarta): 80 Km.

Letak Desa Tanjungsari sangat strategis karena lokasinya berada di titik lalulintas yang dilewati warga kota dari Jakarta menuju kotakota lain seperti Cianjur dan Bandung sehingga kendaraan ramai. Fenomena pertumbuhan penduduk dari tahun ke tahun yang semakin meningkat membuat perkembangan juga menjadi meningkat mengikuti pertumbuhan penduduk tersebut. Seiring meningkatnya laju pertumbuhan dan perkembangan di daerah sekitarnya, Desa Tanjungsari juga mulai diincar oleh pengusaha dari dalam maupun dari luar Desa Tanjungsari, seperti dari Jakarta, Bekasi, Depok dan daerah lain.

Dengan perkembangan tersebut mulai ada transaksi atau jual beli antara pemilik tanah dengan pembeli. Tim Peneliti mencoba menyoroti model transaksi jual beli di Desa Tanjungsari yang masih dilakukan secara adat yang hanya dibuktikan dengan tanda pembayaran berupa kuitansi atau pernyataan di atas kertas segel/bermaterai dan disaksikan oleh Kepala Desa/tokoh masyarakat.

Menurut hukum adat, jual beli tanah adalah suatu perbuatan pemindahan hak atas tanah yang bersifat terang dan tunai. Terang berarti perbuatan pemindahan hak tersebut harus dilakukan dihadapan kepala adat, yang berperan sebagai pejabat yang menanggung keteraturan dan sahnya perbuatan pemindahan hak tersebut sehingga perbuatan tersebut diketahui oleh umum. Tunai maksudnya, bahwa perbuatan pemindahan hak dan pembayaran harganya dilakukan secara serentak. Oleh karena itu, maka tunai mungkin berarti harga 
tanah dibayar secara kontan, atau baru dibayar sebagaian. Dalam hal pembeli tidak membayar sisanya, maka penjual tidak dapat menuntut atas dasar terjadinya jual beli tanah, akan tetapi atas dasar hukum utang piutang. ${ }^{4}$

Berdasarkan penelusuran dan wawancara yang dilakukan Tim Peneliti di Desa Tanjungsari diperoleh fakta bahwa terkadang seorang pembeli tanah dalam pelaksanaan jual belinya belum tentu mempunyai uang tunai sebesar harga tanah yang disepakati. Dengan demikian pada saat terjadi proses jual beli, uang pembayaran dari harga tanah yang ditetapkan belum dibayar lunas. Belum lunasnya pembayaran harga tanah yang ditetapkan tidak menghalangi pemindahan hak atas tanahnya, artinya proses jual beli dianggap telah selesai. Sedangkan sisa pembayaran yang belum dibayarkan oleh pembeli kepada penjual dianggap sebagai utang dari penjual kepada pembeli, sehingga hubungan antara penjual dengan pembeli merupakan hubungan utang piutang.

Prosedur jual beli tanah pada sebagian masyarakat Desa Tanjungsari, sebelumnya diawali dengan kata sepakat antara calon penjual dengan calon pembeli mengenai obyek jual beli berupa tanah yang akan dijual dan harganya yang dilakukan melalui musyawarah. Setelah terjadi kesepakatan antara penjual dan pembeli terkait obyek tanah dan harganya, biasanya sebagai tanda jadi calon pembeli akan memberikan uang panjer. Dengan diberikannya panjer maka akan terjadi ikatan moral antara calon pembeli dan calon penjual yang dapat menimbulkan hak ingkar. Artinya jika calon pembeli ingkar, maka uang panjer akan menjadi hak calon penjual dan tidak boleh diminta kembali oleh calon pembeli. Sebaliknya apabila yang ingkar adalan calon penjual, maka calon pembeli bisa meminta kembali uang panjarnya kepada calon penjual. Jika para pihak tidak menggunakan hak ingkar tersebut, selanjutnya dapat diselenggarakan pelaksanaan jual beli, dengan calon pembeli dan calon penjual menghadap Kepala Desa Tanjungsari untuk menyampaikan maksud transaksi jual beli tanahdiantara para pihak. Untuk keperluan jual beli obyek tanah tersebut akan dibuatkan surat pernyataan/akte jual beli diatas kertas segel atau kertas bermaterai yang isinya menyatakan kalau calon penjual adalah benar sebagai pemilik sah atas obyek tanah yang berniat menjualnya kepada calon pembeli dan telah menerima uang pembayarannya dari calon pembeli. Surat pernyataan/akte jual beli tersebut kemudian ditandatangani oleh penjual dan pembeli serta Kepala Desa Tanjungsari. Dengan telah ditandatanganinya surat pernyataan/akte jual beli tersebut, maka perbuatan jual beli telah selesai. Pembeli kini menjadi pemegang hak atas tanahnya yang baru dan sebagai buktinya adalah surat pernyataan/ akte jual beli diatas segel atau materai tersebut.

Transaksi jual beli tanah dalam sistem hukum adat mempunyai 3 muatan, yakni:

a. Pemindahan hak atas tanah atas dasar pembayaran tunai sedemikian rupa dengan hak untuk mendapatkan tanahnya kembali setelah membayar sejumlah uang yang pernah dibayarnya. Antara lain menggadai, menjual gade, adil sende, ngejual akad atau gade.

b. Pemindahan hak atas tanah atas dasar pembayaran tunai tanpa hak untuk membeli 
kembali, jadimenjual lepas untuk selamalamanya, antara lain adol plas, runtemurun, menjual jaja.

c. Pemindahan hak atas tanah atas dasar pembayaran dengan perjanjian bahwa setelah beberapa tahun panendan tanpa tindakan hukum tertentu tanah akan kembali (menjual tahunan, adol oyodan)..$^{5}$

Dari hasil wawancara dengan Kepala Desa Tanjungsari beserta Sekertaris dan beberapa warga Desa Tanjungsari sebagai sample serta menelusuri kehidupan sosial ekonomi masyarakat Desa Tanjungsari, maka diperoleh informasi terkait hal-hal yang menyebabkan terjadinya jual beli tanah dengan model sistem hukum adat, antara lain:

1. Pada umumnya masyarakat Desa Tanjungsari menginginkan proses jual beli tanah dilakukan dihadapan PPAT berikut dibuatkan akte jual belinya, namun mereka terbentur dengan prosedur yang panjang dan berbelit serta biaya, sehingga mereka lebih memilih untuk melakukan model jual beli tanah secara adat yang lebih sederhana, yakni hanya dengan dibuatkan surat pernyataan diatas kertas segel atau bermaterai yang isinya penjual menyatakan bahwa dirinya adalah pemilik sah atas tanah yang menjadi obyek jual beli dan akan dijual kepada pembeli sesuai dengan harga yang disepakati. Selanjutnya dimintakan tandatangan pembeli dan penjual serta Kepala Desa Tanjungsai sebagai saksi. Meskipun mereka sadar bahwa hal tersebut tidak sesuai dengan peraturan perundangundangan yang berlaku dan mempunyai risiko apabila salah satu pihak dari mereka mempunyai itikad tidak baik.

2. Masyarakat Desa Tanjungsari beranggapan bahwa jangka waktu yang diperlukan untuk proses jual beli hak atas tanah melalui PPAT terlalu lama, dan melalui tahapantahapan cukup panjang seperti mengurus kelengkapan surat-surat lainnya.

3. Selain itu, ada alasan lain yang menyebabkan masyarakat Desa Tanjungsari melakukan model jual beli tanah secara adat, yakni masih kurangnya kesadaran hukum untuk memahami peraturan perundang-undangan dalam bidang pertanahan khususnya dalam hal peralihan hak atas tanah.

Faktor-faktor yang menyebabkan terjadinya jual beli tanah dengan model sistem hukum adat, lebih dipengaruhi karena tidak efektifnya UUPA jo. PP No. 24 Tahun 1997 untuk diterapkan pada sebagian masyarakat Desa Tanjungsari. Menurut Soerjono Soekanto, efektif atau tidaknya suatu hukum ditentukan oleh 5 (lima) faktor, yaitu :

1. Faktor hukumnya sendiri (undang-undang)

2. Faktor penegak hukum, yakni pihak-pihak yang membentuk dan menerapkan hukum

3. Faktor sarana atau fasilitas yang mendukung penegakan hukum

4. Faktor masyarakat, yakni lingkungan dimana hukum tersebut berlaku atau diterapkan

5. Faktor kebudayaan, yakni sebagai hasil karya, cipta dan rasa yang didasarkan pada karsa. $^{6}$

Berdasarkan hal tersebut, maka kecenderungan pada sebagian masyarakat Desa

Iman Sudiyat, Hukum Adat Seketsa Asas (Yogyakarta:Liberty, 1981), hlm. 28.

6 Soerjono Soekanto, Faktor-Fakor Yang Mempengaruhi Penegakan Hukum (Jakarta:PT. Raja Grafindo Persada, 2008), hlm. 8. 
Tanjungsari yang masih melakukan jual beli tanah melalui sistem adat disebabkan oleh faktor-faktor antara lain :

1. Faktor hukumnya, yakni tidak adanya unsur pemaksa dan sanksi yang tegas terhadap pelanggaran PP No. 24 Tahun 1997, terkait pelaksanaan transaksi jual beli tanah yang dilakukan tanpa melalui PPAT.

2. Faktor sarana atau fasilitas, yakni belum terbentuknya suatu organisasi kemasyarakatan yang mampu menciptakan hubungan yang kondusif antar maasyarakat dengan segala keperluannya termasuk salah satunya mengenai pelaksanaan transaksi jual beli tanah.

3. Faktor masyarakat, yakni belum terciptanya kesadaran bagi masyarakat untuk mematuhi suatu peraturan perundang-undangan.

4. Faktor kebudayaan, yakni masih berpegang pada hukum adat secara turun temurun dengan berpedoman saling percaya satu sama lain dalam melakukan transaksi jual beli tanah.

\section{Implementasi PP No. 24 Tahun 1997 Dikaitkan Dengan Model Jual Beli Menurut Hukum Adat Di Desa Tanjungsari.}

Masih adanya model jual beli menurut hukum adat seperti halnya yang terjadi pada sebagian masyarakat Desa Tanjungsari menunjukkan implementasi PP No. 24 Tahun 1997 tentang Pendaftaran Tanah belum dapat berjalan secara baik.

Dalam implementasi PP No. 24 Tahun 1997 tentang pendaftaran tanah, keberadaan PPAT memiliki peran yang sangat penting dalam mengeluarkan Akta Jual Beli. Hal mana berdasarkan ketentuan Pasal 6 ayat (2) PP No. 24 Tahun 1997, ditegaskan bahwa dalam melaksanakan pendaftaran tanah, Kepala Kantor Pertanahan dibantu oleh PPAT dan pejabat lain yang ditugaskan untuk melaksanakan kegiatan-kegiatan tertentu menurut peraturan pemerintah ini dan peraturan perundangan yang bersangkutan.

Tugas pokok PPAT menurut Pasal 2 PP No. 37 Tahun 1998 tentang Peraturan Jabatan Pejabat Pembuat Akta Tanah, ialah bertugas melaksanakan sebagian kegiatan pendaftaran tanah dengan membuat akta sebagai bukti telah dilakukannya perbuatan hukum tertentu mengenai hak atas tanah atau hak milik atas satuan rumah susun yang akan dijadikan dasar bagi pendaftaran perubahan data pendaftaran tanah yang diakibatkanoleh perbuatan hukum itu.

Pasal 19 ayat (1) UUPA menentukan bahwa untuk menjamin kepastian hukum oleh pemerintah diadakan pendaftaran di seluruh wilayah Republik Indonesia menurut ketentuan-ketentuan yang diatur dengan Pasal 19 ayat (2) PP No. 24 Tahun 1997 menentukan pendaftaran tanah tersebut meliputi: a. pengukuran, pemetaan, dan pembukuan tanah; b. pendaftaran hak-hak atas tanah dan peralihan hak-hak tersebut; c. pemberian suratsurat tanda bukti hak yang berlaku sebagai alat pembuktian yang kuat.

Tujuan pendaftaran tanah sebagaimana dimaksud dalam Pasal 3 PP Nomor 24 Tahun 1997, diantaranya :

1. Untuk memberikan kepastian dan perlindungan hukum kepada pemegang hak atas sebidang tanah, satuan rumah susun, dan hak-hak lain yang terdaftar agar dengan mudah dapat membuktikan dirinya sebagai pemegang hak yang bersangkutan, untuk itu kepada pemegang hak diberikan sertifikat. 
2. Untuk menyediakan informasi kepada pihakpihak yang berkepentingan termasuk pemerintah agar dengan mudah dapat memperoleh data yang diperlukan dalam mengadakan perbuatan hukum mengenai bidang-bidang tanah dan satuan-satuan rumah susun yang sudah terdaftar. Untuk melaksanakan fungsi informasi tersebut, data fisik dan yuridis sebidang tanah dan satuan ruamh susun yang terdaftar terbuka untuk umum.

3. Untuk terselenggaranya tertib administrasi pertanahan.

Bagi masyarakat yang tinggal di pedesaan seperti halnya Desa Tanjungsari, jika jual beli diharuskan dengan Akta PPAT, maka hak-hak masyarakat Desa Tanjungsari merasa dibatasi didalam jual beli tanah. Seharusnya Badan Pertanahan Nasional/Kantor Pertanahan Kabupaten/Kota mengantisipasi keadaan ini dalam rangka pendaftaran tanah dan penerbitan sertifikatnya sebagai perlindungan hak-hak masyarakat pedesaan untuk memperoleh kepastian pemilikan tanah. Ditinjau secara sosialekonomis jelas akan merugikan masyarakat umum. Dengan demikian tujuan kesederhanaan dalam hukum yang dikehendaki oleh pembeli tidak tercapai. Tujuan yang mensahkan sesuatu perbuatan yang sudah diharuskan oleh undangundang secara mengikat akan membuat undang-undang sendiri menjadi lemah. ${ }^{7}$

Untuk mendukung perbuatan hukum pendaftaran tanah, keabsahan akta jual beli tanah tergantung pada ketaatan PPAT menjalankan kewenangan jabatannya, yaitu: 1) Sertifikat yang menjadi objek perjanjian jual beli tanahtidak sedang dijadikan agunan bank, sengketa, dan/atau dalam sitaan; 2) Sertifikat yang menjadi objek perjanjian jual beli masih dalam permohonan hak di Kantor Pertanahan Kabupaten/Kota; 3) Sertifikat tanah atas nama orang lain; 4) Pembeli belum cukup umur; 5) Calon pembeli yang ingin membeli tanah (khusus untuk tanah sawah) tidak berdomisili di wilayah tempat tanah itu berada; 6) Para pihak atau salah satunya belum cukup umur untuk melakukan jual beli; 7) Hak atas tanah berada dalam sengketa; 8) Hak atas tanah dalam sitaan Pengadilan Negeri, atau sudah diserahkan kepada Panitia Urusan Piutang Negara dan belum disita oleh PUPN; 9) Bukan badan hukum yang berdasarkan PP No. 38 Tahun 1963 diperkenankan memiliki tanah dengan hak milik; 10) Bidang tanah terletak diluar wilayah kerja PPAT; 11) Calon pembeli tanah adalah orang asing; 12) Tanah wakaf dan tanah yang sedang digadaikan. ${ }^{8}$

Dalam rangka percepatan pendaftaran tanah telah diterbitkan Peraturan Menteri Agraria dan Tata Ruang/Kepala BPN No. 35 Tahum 2016 tentang Percepatan Pelaksanaan Pendaftaran Tanah Sistematis Lengkap sebagaimana diubah dengan Peraturan Menteri Agraria dan Tata Ruang/Kepala BPN No. 1 Tahun 2017 tentang Perubahan Atas Peraturan Menteri Agraria dan Tata Ruang/Kepala BPN No. 35 Tahun 2016 tentang Percepatan Pelaksanaan Pendaftaran Tanah Sistematis Lengkap. Peraturan tersebut merupakan acuan kegiatan sertifikasi tanah secara massal yang diarahkan secara sistematis.

Mengenai pemahaman masyarakat Desa Tanjungsari terkait dengan dengan proses

Adrian Sutedi, Sertifikat Hak Atas Tanah (Jakarta: Sinar Grafika, 2012), hlm. 137-138.

8 Sunindia dan Ninik Widayanti, Pembaharuan Hukum Agraria Beberapa Pemikiran (Jakarta:Bina Aksara, 1988) hlm. 122-123. 
pendaftaran tanah sebagaimana diatur dalam PP No. 24 Tahun 1997, sebagian masyarakat Desa Tanjungsari sudah memiliki pemahaman sudah memiliki pemahamn yang baik mengenai proses pendaftaran tanah hal ini dapat dilihat dari tingginya minat masyarakat untuk untuk mengajukan pembuatan sertifikat kepemilikan hak tanah, namun demikian tidak dipungkiri pula masih terdapat sebagian dari masyarakat Desa Tanjungsari yang belum paham atau kurang memiliki kesadaran untuk melakukan pendaftaran tanah.

Berdasarkan keterangan tentang kebijakan pendaftaran tanah, dapat diketahui BPN Kabupaten Bogor sudah melaksanakan berbagai upaya agar masyarakat dapat mendukung berpartisipasi aktif mendaftarakan tanah miliknya kepada BPN KAbupaten Bogor. Namun demikian Sebagian masyarakat Desa Tanjungsari masih memiliki penilaian kurang maksimal terhadap layanan BPN yang biasanya memakan waktu yang cukup lama dalam proses pendaftaran tanah.

Hasil wawancara juga mengungkapkan bahwa, tanah yang diperjualbelikan pada sebagian masyarakat Desa Tanjungsari tidak memiliki akta jual beli yang dibuat PPAT karena dilakukan dengan sistem hukum adat. Kondisi ini mengakibatkan proses pengurusan pendaftaran tanah menjadi terhambat, serta berpengaruh kecepatan standar waktu pengurusan pendaftaran tanah.

\section{Proses Pendaftaran Tanah Untuk Mendapatkan Sertifikat Sebagai Bukti Kepemilikan Hak Atas Tanah Yang Dibeli Dengan Model Jual Beli Menurut Sistem Hukum Adat.}

Model jual beli tanah menurut sistem hukum adat sebagaimana terjadi pada sebagian masyarakat Desa Tanjungsari, yang pembuatan akta jual belinya tidak dilakukan melalui PPAT, namun hanya didasarkan surat pernyataan/ akte jual beli diatas kertas segel atau kertas bermaterai saja tentunya akan menimbulkan kendala tersendiri jika hendak mengurus pendaftaran atas tanah yang baru dibelinya dalam rangka mendapatkan sertifikat sebagai bukti kepemilikan. Hal mana sebagaimana disyaratkan pasal 19 UUPA jo. Pasal 37 ayat (1) PP No. 24 Tahun 1997 menyebutkan, peralihan hak atas tanah hanya dapat didaftarkan jika dibuktikan dengan akta yang dibuat oleh PPAT.

Salah satu kegiatan pendaftaran tanah ialah kegiatan pemeliharaan data pendaftaran tanah, khususnya jika terjadi peralihan hak atas tanah, pemindahan hak dalam rangka likuidasi dan pembebanan hanya dapat didaftar jika dibuktikan dengan dengan akta yang dibuat PPAT. Ketentuan ini merupakan penegasan bahwa fungsi PPAT berada dalam rangkaian pelaksanaan pendaftaran tanah, yaitu membantu Kepala Kantor Pertanahan sebagai pelaksana pendaftaran tanah dengan menyediakan alat-alat buktiyang akan dijadikan dasar bagi pendaftaran perubahan data tanah tertentu. Oleh karena itu dibutuhkan ketepatan, kepastian dan kebenaran informasi yang tertuang dalam akte yang dibuatnya sebagai sarana yang sangat menentukan proses pendaftaran tanah dan perlindungan hak atas tanah warga masyarakat. Konsekuensinya PPAT disamping harus bertanggungjawab terhadap 
kepastian dan kebenaran isi akte, ia juga wajib menyampaikan akte dan warkah-warkah lainnya kepada Kantor Pertanahan. ${ }^{9}$

Menurut Pasal 23 PP No. 24 Tahun 1997, prosedur pengurusan hak atas tanah baru dibuktikan dengan, Asli akta PPAT yang memuat pemberian hak tersebut oleh pemegang hak milik kepada penerima hak yang bersangkutan apabila mengenai hak guna bangunan dan hak pakai atau tanah milik.

Menurut Waskito, dalam hal bukti kepemilikan tanah masyarakat tidak lengkap atau tidak ada sama sekali, termasuk bukti kepemilikan atas hak tanah yang dibeli dengan model jual beli menurut sistem hukum adat, maka dalam rangka proses pendaftaran tanah untuk mendapatkan sertifikat dapat dilengkapi dan dibuktikan dengan surat pernyataan tertulis tentang penguasaan fisik bidang tanah dengan iktikad baik oleh yang bersangkutan. Unsur-unsur iktikad baik terdiri dari secara fisik menguasai, menggunakan, memanfaatkan dan memelihara tanah secara turun-temurun dalam waktu tertentu dan/atau memperoleh dengan cara tidak melanggar ketentuan peraturan perundang-undangan. Untuk membuktikan iktikad baik, pemohon membuat pernyataan yang menyatakan: a) tidak terdapat keberatan dari pihak lain atas tanah yang dimiliki atau tidak dalam keadaan sengketa; b) tidak termasuk atau bukan merupakan aset pemerintahan, aset pemerintahan daerah, atau aset Badan Usaha Milik Negara/Badan Usaha Milik Daerah. ${ }^{10}$

Sebagaimana pemahaman tersebut diatas, meskipun model jual beli dilakukan melalui sistem adat atau tanpa melalui
PPAT, masyarakat Desa Tanjungsari tetap bisa melakukan pendaftaran tanah miliknya untuk mendapatkan sertifikat, dengan syarat permohonan pendaftarannya dilengkapi dan dibuktikan dengan surat pernyataan tertulis tentang penguasaan fisik bidang tanah dengan iktikad baik dengan menyatakan, tidak terdapat keberatan dari pihak lain atas tanah yang dimiliki atau tidak dalam keadaan sengketa serta bukan merupakan aset pemerintahan.

\section{Penutup}

Berdasarkan uraian di atas, maka dapat dikemukakan simpulan sebagai berikut:

1. Faktor-faktor yang menyebabkan sebagian masyarakat Desa Tanjungsari masih menggunakan model jual beli tanah melalui sistem hukum adat antara lain, karena tidak adanya unsur pemaksa dan sanksi yang tegas terhadap pelanggaran PP No. 24 Tahun 1997 terkait pelanggaran pelaksanaan transaksi jual beli tanah, dan belum terciptanya kesadaran masyarakat untuk mematuhi suatu peraturan perundang-undangan, serta masyarakat masih berpegang pada hukum adat secara turun temurun dengan berpedoman saling percaya satu sama lain dalam melakukan transaksi jual beli tanah.

2. Masih adanya model jual beli menurut hukum adat seperti halnya yang terjadi pada sebagian masyarakat Desa Tanjungsari menunjukkan implementasi PP No. 24 Tahun 1997 tentang Pendaftaran Tanah belum dapat berjalan secara baik.

3. Masyarakat Desa Tanjungsari tetap bisa melakukan pendaftaran atas tanah miliknya

9 Samun Ismaya, Hukum Administrasi Pertanahan (Yogyakarta : Graha Ilmu, 2013), hlm. 89.

10 Waskito dan Hadi Arnowo, Pertanahan Agraria, dan Tata Ruang (Jakarta:Kencana, 2017), hlm. 114. 
untuk mendapatkan sertifikat, dengan syarat permohonan pendaftarannya dilengkapi dan dibuktikan dengan surat pernyataan tertulis tentang penguasaan fisik bidang tanah dengan iktikad baik dengan menyatakan, tidak terdapat keberatan dari pihak lain atas tanah yang dimiliki atau tidak dalam keadaan sengketa serta bukan merupakan aset pemerintahan.

Adapun saran yang dapat disampaikan oleh Tim Peneliti adalah:

1. Perlu dilakukan sosialisasi dan penyuluhan hukum mengenai pentingnya perbuatan hukum jual beli hak atas tanah yang dibuat dihadapan PPAT sebagaimana diatur dalam PP Nomor 24 Tahun 1997 sebagai pelaksanaan dari UUPA, dengan harapan wawasan pengetahuan masyarakat menjadi terbuka dan tercipta tertib administrasi pertanahan.

2. Aparat Pemerintah Desa Tanjungsari, Kabupaten Bogor diharapkan dapat mengaktifkan kembali fasilitas kelembagaan dalam bidang pertanahan untuk dapat memberikan informasi dan meningkatkan pengetahuan masyarakat tentang peraturanperaturan terkait bidang pertanahan, termasuk tata cara jual beli melalui PPAT dan pendaftarannya pada kantor pertanahan setempat.

3. Pemerintah diharapkan mampu meningkatkan kualitas Pejabat Pertanahan terkait untuk aktif memberikan pendampingan bagi masyarakat dalam memberikan pelayanan dan pemahaman tentang peraturan yang berkaitan dengan perjanjian jual beli tanah dan juga peraturan lainnya, sehingga masyarakat dapat mengetahui setiap peraturan yang ada, dengan harapan masyarakat Desa
Tanjungsari, Kabupaten Bogor dapat mengetahui dan menerapkan peraturan dalam setiap pelaksanaan transaksi jual beli tanah.

\section{DAFTAR PUSTAKA}

\section{Buku}

Ismaya, Samun, Hukum Administrasi Pertanahan (Yogyakarta : Graha Ilmu, 2013).

R. Soeprapto, Undang-Undang Agraria Dalam Praktik (Jakarta : Mitra Sari, 1966).

Rosnidar, Hukum Pertanahan Adat (Depok : Rajawali Pers, 2017).

Santoso, Urip, Hukum Agraria \& Hak-Hak Atas Tanah (Jakarta : Kencana Prenada Media Group, 2009).

Soekanto, Soerjono, Faktor-Fakor Yang Mempengaruhi Penegakan Hukum (Jakarta : PT. Raja Grafindo Persada, 2008).

Soekanto, Sukanto, Hukum Adat Indonesia (Jakarta : Rajawali, 1983).

Sudiyat, Imam, Asas-asas Hukum Adat, Bekal Pengantar (Yogyakarta : Liberty, 1978).

Sudiya, Imam, Hukum Adat Seketsa Asas (Yogyakarta : Liberty, 1981 ).

Sunindhia, Y.W. dan Ninik Widayanti, Pembaharuan Hukum Agraria (Beberapa Pemikiran) Cet. 1 (Jakarta : Bina Aksara, 1988).

Sutedi, Adrian, Peralihan Hak Atas Tanah Dan Pendaftarannya (Jakarta : Sinar Grafika, 2013).

Sutedi, Adrian, Sertifikat Hak Atas Tanah (Jakarta : Sinar Grafika, 2012).

Waskito, dkk., Pertanahan Agraria, dan Tata Ruang (Jakarta : Kencana, 2017).

Wulansari, Dewi, Hukum Adat Indonesia Suatu Pengantar (Jakarta : Rafika Aditama, 2010).

\section{Peraturan Perundang-undangan}

Undang-Undang Nomor 5 Tahun 1960 tentang Peraturan Dasar Pokok-Pokok Agraria.

Peraturan Pemerintah Nomor 24 Tahun 1997 tentang Pendaftaran Tanah.

Peraturan Pemerintah Nomor 37 Tahun 1998 tentang Peraturan Jabatan Pejabat Pembuat Akta Tanah.

Keputusan Menteri Dalam Negeri Nomor 189 Tahun 1981 Tentang Proyek Operasi Nasional Agraria.

Peraturan Menteri Agraria dan Tata Ruang/Kepala BPN Nomor 1 Tahun 2017 tentang Perubahan Atas Peraturan Menteri Agraria dan Tata 
Ruang/Kepala BPN No. 35 Tahun 2016 tentang Percepatan Pelaksanaan Pendaftaran Tanah Sistematis Lengkap. 
"Halaman ini dikosongkan" 